\title{
Recent patents in biosensor technology
}

\begin{tabular}{|c|c|c|c|c|c|}
\hline Patent \# & Subject & Assignee & Inventor(s) & $\begin{array}{l}\text { Priority } \\
\text { application } \\
\text { date }\end{array}$ & $\begin{array}{l}\text { Publication } \\
\text { date }\end{array}$ \\
\hline US 20010042683 & $\begin{array}{l}\text { A biosensor for detecting the electrical current required } \\
\text { to perform a valid test for determining analyte concentration } \\
\text { in a fluid sample. A current detector is programmed to emit } \\
\text { an error signal when the flow of electrical current } \\
\text { is insufficient. }\end{array}$ & $\begin{array}{l}\text { Bayer } \\
\text { (Leverkusen, } \\
\text { Germany) }\end{array}$ & $\begin{array}{l}\text { Edelbrock AJ, } \\
\text { Musho MK, } \\
\text { Noell JO }\end{array}$ & $12 / 8 / 2000$ & $11 / 22 / 2001$ \\
\hline DE 20104431 & $\begin{array}{l}\text { A sensor electrode arrangement comprising an electrically } \\
\text { conductive electrode region, which in operation is inserted into } \\
\text { a test medium adjacent to primary carriers in direct proximity } \\
\text { to an electrically activatable biological unit; useful in biosensors } \\
\text { for amperometric and/or potentiometric drug testing. }\end{array}$ & $\begin{array}{l}\text { IonGate } \\
\text { Biosciences } \\
\text { (Frankfurt, } \\
\text { Germany) }\end{array}$ & - & $3 / 15 / 2001$ & $10 / 31 / 2001$ \\
\hline DE 19951509 & $\begin{array}{l}\text { A process for applying a lipid double layer to a substrate } \\
\text { surface, comprising contacting with a lipid-comprising } \\
\text { solution, an organic solvent miscible with water, and optionally } \\
\text { water; used in the production of biosensors. }\end{array}$ & $\begin{array}{l}\text { BioTul } \\
\text { (Munich, } \\
\text { Germany) }\end{array}$ & Raedler J & 10/26/1999 & $10 / 31 / 2001$ \\
\hline WO 200179848 & $\begin{array}{l}\text { A method for reversibly binding a receptor to a sensor surface; } \\
\text { useful for identifying or isolating specific ligands by attaching } \\
\text { to a coupling agent that binds to an antibody on the surface, } \\
\text { and in the construction of biosensors used to determine } \\
\text { specific binding reactions. }\end{array}$ & $\begin{array}{l}\text { Netherlands } \\
\text { Organization } \\
\text { for Applied } \\
\text { Scientific } \\
\text { Research } \\
\text { (Delft) }\end{array}$ & $\begin{array}{l}\text { Stigter ECA, } \\
\text { van Hoevel van } \\
\text { Wezeveld SWF, } \\
\text { Gaspari M, } \\
\text { van der Gaag A, } \\
\text { van Hoevell } \\
\text { Tot Westerflier S, } \\
\text { Verheij ER }\end{array}$ & $\begin{array}{l}5 / 25 / 2000 \\
\end{array}$ & $10 / 25 / 2001$ \\
\hline EP 1147739 & $\begin{array}{l}\text { A monitoring system comprising a biosensing meter that } \\
\text { includes a controller to conduct a biosensing test on a bodily } \\
\text { fluid (e.g., coagulation time or glucose levels). The controller } \\
\text { activates the biological sensing meter upon receipt of an } \\
\text { activation code, guarding against fraudulent activity. }\end{array}$ & $\begin{array}{l}\text { Roche } \\
\text { Diagnostics } \\
\text { (Indianapolis, } \\
\text { IN; Mannheim, } \\
\text { Germany) }\end{array}$ & $\begin{array}{l}\text { Cronrath C, } \\
\text { Essenpreis M, } \\
\text { Gerber MT, } \\
\text { Hansen MV }\end{array}$ & 4/18/2000 & $10 / 24 / 2001$ \\
\hline US 6303290 & $\begin{array}{l}\text { A method of preparing a porous matrix comprising adding } \\
\text { biological material to a solution of a ceramic oxide colloidal } \\
\text { sol and dissolved sodium silicate; useful for encapsulating } \\
\text { biomolecules that are useful in drug delivery, and as implants, } \\
\text { bioreactors, and biosensors. }\end{array}$ & $\begin{array}{l}\text { University of } \\
\text { Pennsylvania } \\
\text { (Philadephia) }\end{array}$ & $\begin{array}{l}\text { Chen I, } \\
\text { Liu D }\end{array}$ & $9 / 13 / 2000$ & $10 / 16 / 2001$ \\
\hline WO 200175089 & $\begin{array}{l}\text { A polymer matrix incorporating catalase, which is co- } \\
\text { immobilized with an analytic enzyme that generates } \\
\text { hydrogen peroxide; useful in biosensors and in controlled } \\
\text { drug-delivery systems. }\end{array}$ & $\begin{array}{l}\text { M-Biotech } \\
\text { (Salt Lake } \\
\text { City, UT) }\end{array}$ & $\begin{array}{l}\text { Dal-Young J, } \\
\text { Han IS }\end{array}$ & $4 / 3 / 2000$ & $10 / 11 / 2001$ \\
\hline WO 200175149 & $\begin{array}{l}\text { A biosensor with a region for retaining probe molecules } \\
\text { that is able to bind to macromolecular biopolymers; useful } \\
\text { for detecting proteins, peptides, and nucleic acids. }\end{array}$ & $\begin{array}{l}\text { Infineon } \\
\text { Technologies } \\
\text { (Munich, } \\
\text { Germany) }\end{array}$ & $\begin{array}{l}\text { Thewes R, } \\
\text { Weber W }\end{array}$ & 3/30/2000 & $10 / 11 / 2001$ \\
\hline WO 200173420 & $\begin{array}{l}\text { An electrochemical biosensor measuring device with sensor } \\
\text { chips for various reagents and differing calibration curves; } \\
\text { useful in determining serum sugar, cholesterol, and lactic } \\
\text { acid levels in blood. }\end{array}$ & $\begin{array}{l}\text { Matsushita } \\
\text { Denki Sangyo } \\
\text { KK; Matsushita } \\
\text { Electric Ind. } \\
\text { Co. Ltd. } \\
\text { (Osaka, Japan) }\end{array}$ & Tokuno Y & $3 / 30 / 2000$ & $10 / 4 / 2001$ \\
\hline JP 2001228110 & $\begin{array}{l}\text { A biosensor installed with a water analyzer, comprising a fixed } \\
\text { microorganism film and buffer solution for } \mathrm{pH} \text { regulation; useful } \\
\text { for monitoring the quality of water such as river water, waste } \\
\text { treatment water, and underground water. }\end{array}$ & $\begin{array}{l}\text { Fuji Electric } \\
\text { Co. Ltd. } \\
\text { (Tokyo) }\end{array}$ & - & $2 / 15 / 2000$ & $8 / 24 / 2001$ \\
\hline JP 2001208722 & $\begin{array}{l}\text { A limiting current-type gas sensor with an electrolyte-containing } \\
\text { material; useful as a biosensor for clinical laboratories and for } \\
\text { measuring oxygen concentration in the atmosphere and liquids. }\end{array}$ & $\begin{array}{l}\text { Toyota Chuo } \\
\text { Kenkyusho } \\
\text { (Aichi-gun, } \\
\text { Japan) }\end{array}$ & - & $1 / 24 / 2000$ & $8 / 3 / 2001$ \\
\hline
\end{tabular}

Source: Derwent Information, Alexandria, VA. The status of each application is slightly different from country to country. For further details, contact Derwent Information, 1725 Duke Street, Suite 250, Alexandria, VA 22314. Tel: 1 (800) DERWENT (info@derwent.com). 